\title{
Struktur Komunitas Dan Keberlanjutan Pengelolaan Ekosistem Mangrove Pulau-Pulau Kecil (Kasus Pada Pulau Nain Kabupaten Minahasa Utara Provinsi Sulawesi Utara)
}

\author{
Joshian Nicolas William Schaduw
}

Fakultas Perikanan dan Ilmu Kelautan, Universitas Sam Ratulangi.Jl. Kampus Unsrat Bahu, Manado 95115, Sulawesi Utara, Indonesia, Email : schaduw@unsrat.ac.id

\begin{abstract}
ABSTRAK
Kajian ini bertujuan untuk menganalisa struktur komunitas dan keberlanjutan pengelolaan ekosistem mangrove di Pulau Nain Kecamatan Wori, Kabupaten Minahasa Utara, Provinsi Sulawesi Utara. Pulau Nain adalah salah satu pulau yang masuk dalam kawasan konservasi Taman Nasional Bunaken dan memiliki kawasan budidaya rumput laut yang masih produktif. Penelitian ini menggunakan data sekunder dan primer. Data yang dibutuhkan dalam kajian ini meliputi data dimensi ekologi, sosial ekonomi, dan kelembagaan. Analisis yang digunakan dalam kajian ini adalah RAPMECS (Rapid Appraisal for Mangroves Ecosystem) dengan analisis multy dimensional scaling (MDS). Hasil yang diperoleh dari kajian ini adalah luasan mangrove Pulau Nain sebesar 4.40 ha, memiliki dua jenis mangrove yaitu Rhizophora apiculata dan Avicennia marinna masing-masing dari family Avicenniaceae dan Rhizophoraceae. Indeks nilai penting (INP) jenis tertinggi terlihat pada jenis Rhizophora apiculata (79.64\%) sedangkan jenis Avicennia marinna (79.64\%). Ekosistem mangrove Pulau Nain dalam kondisi yang baik, tapi secara kuantitas belum optimal sebagai buffer sistem lingkungan pesisir. Status keberlanjutan pengelolaan ekosistem mangrove Pulau Nain menunjukkan angka 46,89 yang berarti status keberlanjutan pengelolaan ekosistem mangrove pulau ini berada dalam kondisi cukup baik. Keterisolasian pulau, luasan mangrove yang kecil, luas pulau yang kecil dan rendahnya kualitas sumberdaya manusia membuat pulau ini memiliki nilai yang kurang baik untuk keberlanjutan pengelolaan ekosistem mangrove Pulau Nain. Pemantauan secara berkala dan strategi pengelolaan yang baik dapat meningkatkan indeks keberlanjutan pengelolaan ekosistem mangrove serta meningkatkan kapasitas lingkungan pesisir Pulau Nain.
\end{abstract}

Kata kunci: Keberlanjutan; Pengelolaan; Mangrove; Nain.

\section{ABSTRACT}

The aims of this study are to analyze the community structure and sustainability of mangrove ecosystem management in Nain Island, Wori District, North Minahasa, North Sulawesi Province. Nain Island is one of the islands rlocated in Bunaken National Park conservation area and has productive seaweed cultivation area. This study used secondary and primary data. Data required in this study are included dimension data of ecological, socio-economic, and institutional. The analysis that used in this study was RAPMECS (Rapid Appraisal for Mangroves Ecosystem) through multy dimensional scaling (MDS) analysis. The results obtained from this study are mangroves area in Nain Island was $4.40 \mathrm{ha}$, has two types of mangroves Rhizophora apiculata and Avicennia marinna respectively belong to family Avicenniaceae and Rhizophoraceae. The highest species importance value index (INP) wasfound in Rhizophora apiculata (79.64\%) while Avicennia marinna (79.64\%). Mangrove ecosystem in Nain Island are in good condition, but in quantity not yet optimal as buffer for coastal environment system. The sustainability status of mangrove ecosystem management of Nain Island shows 46.89 which means that the sustainability status of mangrove ecosystem management of this island is in fair condition. Isolation of island small mangrove areas, small islands and low quality of human resources make this island has a poor value for the sustainability of mangrove ecosystem management. Regular monitoring and good management strategies can improve the sustainability index of mangrove ecosystem management and increase the capacity of the coastal environment of Nain Island.

Keywords: Sustainability; Management; Mangrove; Nain

Sitasi: Schaduw J.N.W. (2018). Struktur Komunitas Dan Keberlanjutan Pengelolaan Ekosistem Mangrove Pulau-Pulau Kecil (Kasus Pada Pulau Nain Kabupaten Minahasa Utara Provinsi Sulawesi Utara). Jurnal Ilmu Lingkungan, 16(2), 120129,doi:10.14710/jil.16.2.120-129

\section{Pendahuluan}

Salah satu kawasan konservasi nasional di Indonesia yang memiliki pulau-pulau kecil adalah Taman Nasioal Bunaken. Luas total Taman Nasional Bunaken (TNB) adalah 89. 065 ha TNB terdiri atas dua bagian yaitu TNB bagian Utara dan TNB bagian selatan. TNB bagian utara meliputi 5 pulau yaitu Bunaken, Manado Tua, Mantehage, Siladen dan Nain ditambah sekitaran Tanjung Pisok yaitu antara desa Molas hingga ke desa Tiwoho. Sedangkan TNB bagian Selatan meliputi wilayah perairan dari desa Poopoh hingga ke desa Popareng. TNB memiliki banyak kekayaan sumberdaya alam, diantaranya ketiga ekosistem 
penting pesisir yaitu ekosistem mangrove, padang lamun, dan terumbu karang. Ekosistem mangrove pulau-pulau kecil (PPK) mempunyai fungsi ekologi dan ekonomi, hal ini dapat dikembangkan sebagai basis dari mitigasi terhadap degradasi lingkungan PPK.

Hutan magrove di TNB cukup luas (1528.29 ha) terutama di bagian selatan, sedangkan pada bagian utara ekosistem mangrove terluas ada di Pulau Mantehage (Schaduw, 2015b). Luas hutan mangrove pada PPK TNB sebesar 977.63 ha. Luas total hutan mangrove di TNB sekitar $10 \%$ dari luas total ekosistem mangrove di Sulawesi Utara. TNB termasuk komunitas mangrove yang tua di Asia Tenggara, karena itu disana masih ditemukan mangrove yang berukuran besar dengan diameter di atas $1.5 \mathrm{~m}$ yang pada tempat lain sudah jarang ditemukan (Schaduw, 2016 dan BTNB, 2010).

Pulau Nain adalah pulau kecil yang denga luas daratan 118,16 ha pulau ini memiliki luas mangrove sebesar 4,40 ha atau sekitar $3.75 \%$ dari luas daratan. Pulau ini masuk dalam kawasan Taman Nasional Bunaken (TNB), dari kelima pulau kecil yang ada di
TNB Pulau Nain memiliki keistimewaan karena memiliki kawasan budidaya rumput laut yang hingga saat ini menjadi sentra rumput laut di Sulawesi Utara. Masyarakat pulau ini sebagian besar bermata pencaharian sebagai petani rumput laut dan nelayan. Ekosistem mangrove sebagai buffer sistem lingkungan pesisir memiliki fungsi yang sangat besar dalam menjaga stabilitas lingkungan perairan pulau kecil. Sebagai salah satu ekosistem pesisir yang penting maka keberlanjutan pengelolaan ekosistem mangrove sebaiknya dianalisa pada dimensi ekologi, sosialekonomi, dan kelembagaan. Tujuan penelitian ini adalah menganalisa struktur komuitas mangrove dan keberlanjutan pengelolaan ekosistem mangrove yang ada pada Pulau Nain Kecamatan Wori Kabupaten Minahasa Utara Provinsi Sulawesi Utara. Manfaat kajian ini antara lain sebagai masukkan bagi pemerintah dalam membuat kebijakan dan menciptakan strategi pengelolaan ekosistem mangrove yang terpadu dan berkelanjutan untuk meningkatkan kapasitas masyarakat Pulau Nain.

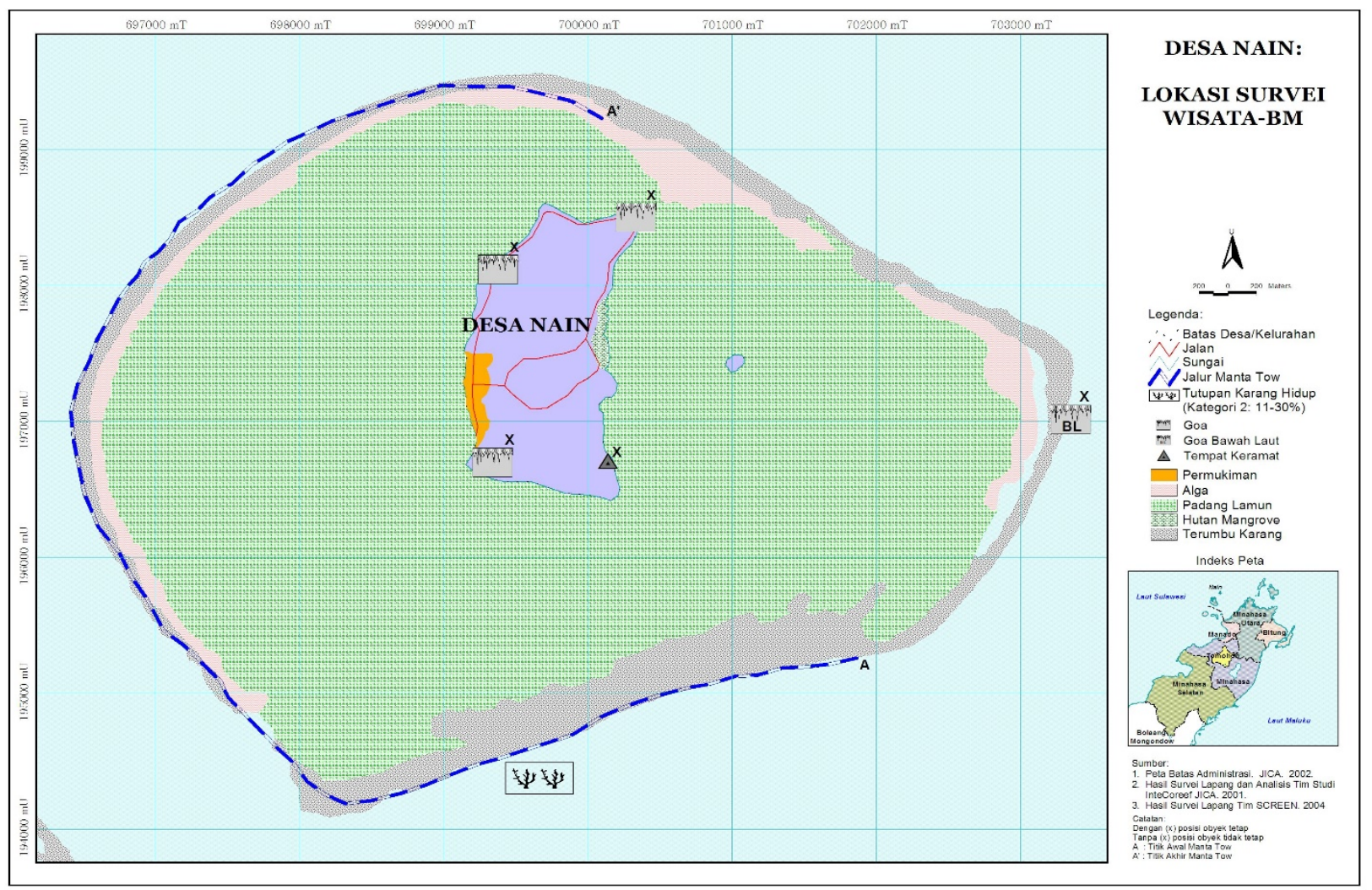

Gambar 1. Peta Lokasi Penelitian Pulau Nain

\section{Metodologi Penelitian}

\subsection{Lokasi dan Waktu Penelitian}

Penelitian ini berlokasi di Pulau Nain Kecamatan Wori Kabupaten Minahasa Utara Provinsi Sulawesi Utara (Gambar 1). Pengumpulan data primer dilakukan dengan mempergunakan metode pengamatan lapangan (observasi) dan metode sampling (stratified, cluster, random, purposive, systematic sampling). Metode observasi merupakan metode yang sangat mendasar dalam melakukan inventarisasi potensi sumberdaya di ekosistem mangrove (Kusumastanto 2002 dan Kusmana et al. 
2005). Data sosial dan ekonomi yang terkait dengan kegiatan penelitian ini akan dikumpulkan di lokasi penelitian dari para responden. Responden akan dipilih secara purposive sampling dan accidental sampling. Pengumpulan data terhadap responden akan dilakukan dengan menggunakan pendekatan wawancara mendalam (deep interview) dengan menggunakan kuisioner (Schaduw, 2015b). Penelitian ini adalah kajian komprehensif yang dimulai dari tahun 2010 - 2017 pada keempat pulau di TNB yang memiliki ekosistem mangrove.

\subsection{Jenis Data dan Analisis}

\subsubsection{Vegetasi Mangrove}

Pengambilan data struktur komunitas vegetasi mangrove dilakukan pada tiga stasiun yang berbeda pada ekosistem mangrove yang ada di Pulau Nain. Setiap stasiun terdiri dari tiga garis transek yang diharapkan dapat mewakili semua struktur komunitas mangrove yang ada di lokasi penelitian. Penetapan arah garis transek dilakukan sesudah melakukan survei komunitas mangrove terlebih dahulu.

Pengambilan data mangrove dilakukan dengan menggunakan metode garis berpetak. Transek tersebut ditarik tegak lurus garis pantai pada setiap stasiun. Pada setiap transek, data diambil dengan menggunakan petak berukuran 10 x $10 \mathrm{~m}^{2}$ untuk kelompok pohon berdiameter $>10 \mathrm{~cm}$ yang ditempatkan di sepanjang garis transek (Schaduw, 2015a). Selanjutnya vegetasi mangrove pada setiap petak diidentifikasi dan diukur diameternya. Alat dan bahan penting yang digunakan dalam pengambilan data ini adalah GPS, meteran, dan tali. GPS digunakan untuk menentukan posisi geografis masing-masing stasiun pengamatan, sedangkan meteran dan tali digunakan untuk membuat garis berpetak pada masing-masing stasiun. Data ini kemudian di tulis dalam tabel pengamatan yang kemudian akan dideskripsikan serta dianalisis indeks nilai pentingnya.

\subsubsection{Analisis Struktur Vegetasi Mangrove}

Analisis yang dilakukan mempunyai tujuan untuk mendapatkan Indeks Nilai Penting (INP) yang merupakan penjumlahan dari frekuensi relatif, kerapatan relatif, dan dominansi relatif. Nilai penting suatu jenis berkisar antara 0 sampai 300. Nilai penting ini memberikan gambaran mengenai pengaruh atau peranan suatu jenis tumbuhan mangrove dalam komunitas mangrove, untuk ketiga komponen INP tersebut dapat dihitung dengan rumus dibawah ini.

- Kerapatan Spesies $\left(D_{i}\right)$

$$
D_{i}=\frac{n_{i}}{A}
$$

$D_{i}=$ kerapatan spesies $\mathrm{i}$

$n_{i}=$ jumlah total individu dari spesies

$A=$ luas area total pengambilan contoh

* Kerapatan Relatif Spesies $\left(R D_{i}\right)$

$$
R D_{i}=\left(\frac{n_{i}}{\sum_{i=1}^{n} n_{i}}\right) \times 100
$$

$\left(R D_{i}\right)=$ Kerapatan relatif spesies

$\left(\mathrm{n}_{\mathrm{i}}\right)=$ Jumlah individu Spesies $\mathrm{i}$

* Frekuensi Spesies $\left(F_{i}\right)$

$$
F_{i}=\frac{p_{i}}{\sum_{i=1}^{n} p_{i}}
$$

$\mathrm{F}_{\mathrm{i}}=$ Frekuensi spesies $\mathrm{i}$

$\mathrm{P}_{\mathrm{i}}=$ Jumlah petak contoh dimana ditemukan spesies I

* Frekuensi Relatif Spesies $\left(R F_{i}\right)$

$$
\begin{aligned}
R F_{i} & =\left(\frac{F_{i}}{\sum_{i=1}^{n} F_{i}}\right) \times 100 \\
R F_{i} & =\text { Frekuensi relatif spesies } \\
F_{i} & =\text { Frekuensi spesies ke } \mathrm{i}
\end{aligned}
$$

* Penutupan Spesies $\left(C_{i}\right)$

$$
C_{i}=\frac{\sum_{i=1}^{n} B A}{A}
$$

$$
\begin{aligned}
\mathrm{BA} & =\pi \mathrm{DBH}^{2}: 4\left(\text { dalam } \mathrm{Cm}^{2}\right) \\
\pi & =\text { konstanta }(3,14) \\
\mathrm{DBH} & =\text { diameter pohon dari jenis } \mathrm{i} \\
\mathrm{A} & =\text { luas area total pengambilan contoh (luas } \\
& \text { total petak/plot/kuadrat) } \\
\mathrm{DBH} & =\mathrm{CBH} / \pi \text { (dalam Cm), DBH adalah lingkaran } \\
& \text { pohon setinggi dada }
\end{aligned}
$$

* Penutupan Relatif Spesies $\left(R C_{i}\right)$

$R C_{i}=\left(\frac{C_{i}}{\sum_{i=1}^{n} C_{i}}\right) \times 100$

$\mathrm{RC}_{\mathrm{i}}=$ Penutupan relatif spesies dan luas total area

$\mathrm{C}_{\mathrm{i}}=$ Luas area penutupan spesies $\mathrm{i}$

* Nilai Penting Spesies $\left(I V_{i}\right)$ 
Jumlah nilai kerapatan relatif spesies $\left(\mathrm{RD}_{\mathrm{i}}\right)$, frekuensi relatif spesies $\left(\mathrm{RF}_{\mathrm{i}}\right)$ dan penutupan relatif spesies $\left(\mathrm{RC}_{\mathrm{i}}\right)$ menunjukkan Nilai Penting Spesies $\left(\mathrm{IV}_{\mathrm{i}}\right)$.

$$
I V_{i}=R D_{i}+R F_{i}+R C_{i}
$$

Pengertian dari beberapa parameter biologi yang diamati di atas adalah :

1. Kerapatan adalah banyaknya individu dari suatu jenis pohon dan tumbuh-tumbuhan lain yang dapat ditaksir atau dihitung.

2. Dominasi adalah jumlah suatu spesies dalam suatu komunitas yang menentukan atau mengendalikan kehadiran spesies lain, atau yang jumlahnya melebihi jenis lain.

3. Frekuensi adalah perbandingan banyaknya ditemukannya suatu jenis terhadap jumlah titik-titik pengukuran seluruhnya.

4. Indeks nilai penting, adalah besaran yang menunjukan kedudukan suatu spesies terhadap spesies lain dalam suatu komunitas.

5. Basal area adalah luas proyeksi dari tumbuhan pada permukaan tanah.

\subsubsection{Analisis Keberlanjutan Pengelolaan Ekosistem Mangrove}

Keberlanjutan pengelolaan ekosistem mangrove (KPEM) Pulau Nain dianalisa menggunakan metode RAPMECS yang menggunakan indeks yang telah dianalisa sebelumnya sebagai atribut dalam pengelolaan (Schaduw, 2015b). Analisis dilakukan dengan memodifikasi pendekatan RAPFISH (Rapid Asessment Technique for Fisheries) yang dikembangkan oleh Fisheries Center, University of British Colombia (Kavanagh 2001; Pitcher \& Preikshot 2001; Alder et al., 2002; Cisse et al., 2014). Indeks keberlanjutan pengelolaan mempunyai selang antara 0-100 (Fauzi dan Anna 2002). Indeks keberlanjutan ini akan menjelaskan kualitas keberlanjutan pengelolaan ekosistem mangrove pulau-pulau kecil untuk memitigasi kerusakan ekosistem dari kegiatan manusia ataupun alamiah dan mengoptimalkan fungsinya. Dengan kategori sangat baik jika sangat baik $(80<\mathrm{KPEM} \leq 100)$, baik $(60<\mathrm{KPEM} \leq 80)$, cukup baik $(40<\mathrm{KPEM} \leq 60)$, buruk $(20<\mathrm{KPEM} \leq 40)$, dan sangat buruk $(0<\mathrm{KPEM} \leq 20)$. Indeks keberlanjutan ini dianalisa pada masing-masing dimensi. Selanjutnya untuk status keberlanjutan dianalisa dengan mengalikan bobot tertimbang hasil wawancara terstruktur dan mendalam terhadap stakeholder kunci yang ada pada masingmasing pulau untuk mengetahui prioritas dari dimensi yang dikaji. Status ini akan memperlihatkan status keberlanjutan secara komprehensif pada masingmasing dimesi. Indeks-indeks ini akan ditampilkan dalam diagram layang-layang dan grafik yang representatif. Analisis Leverage digunakan untuk menentukan nilai faktor yang berpengaruh terhadap keberlanjutan tiap dimensi. Nilai faktor berada pada rentang 2-8 (Pitcher 1999). Apabila terdapat indikator dengan nilai faktor $<2$ merupakan faktor tak berpengaruh, sedangkan nilai $>8$ merupakan faktor sensitif (Theresia et al. 2015). Menurut Susilo (2003) dalam penilaian status keberlanjutan bukan hanya pada pengelompokan dimensi pengelolaan tetapi bagaimana setiap dimensi dapat mencakup indikator seluas mungkin.

Tujuan analisis Multy Dimensional Scaling (MDS) adalah mentransformasi keputusan-keputusan responden tentang similaritas/preferensi yang digambarkan dalam ruang multi dimensi. Bila obyek A dan B diputuskan/dipersepsikan oleh responden sebagai pasangan obyek yang paling serupa. (similar) dari pada semua, pasangan lain yang mungkin, maka MDS akan memposisikan objek A dan B sedemikian rupa sehingga jarak di antara keduanya dalam ruang multi dimensi lebih dekat daripada, jarak antar sembarang pasangan objek yang lain (Hair 1998; Bakus 2000).

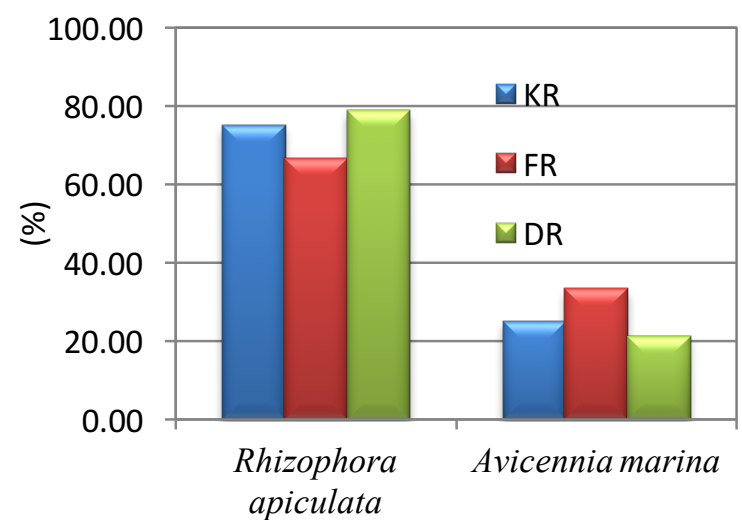

Gambar 2. Kerapatan Relatif, Frekuensi Relatif, dan Dominasi Relatif Mangrove Pulau Nain

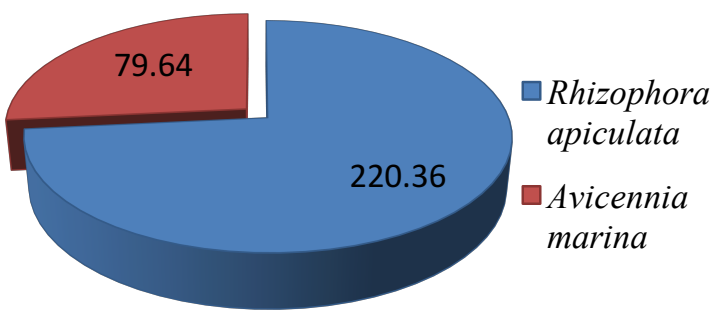

Gambar 3. Indeks Nilai Penting Mangrove Pulau Nain

\section{Hasil dan Pembahsan}

\subsection{Struktur Komunitas}

Pulau Nain adalah pulau terkecil diantara kelima pulau yang ada di Taman Nasional Bunaken. Dengan luas daratan 118.16 ha pulau ini memiliki luas mangrove sebesar 4.40 ha atau sekitar 3.75\% dari luas daratan. Pulau ini memiliki dua jenis mangrove yaitu jenis Rhizophora apiculata dan Avicennia marinna masing-masing dari family Avicenniaceae dan Rhizophoraceae. Keunikan dari ekosistem mangrove desa ini yaitu memiliki jarak pohon terkecil 
$(1,02 \mathrm{~m})$ dibandingkan ekosistem mangrove di pulau yang lain, dengan kepadatan 95,65 individu/100 $\mathrm{m}^{2}$. Hal ini dikarenakan pohon mangrove yang ada di Pulau Nain mempunyai diameter pohon yang kecil, yang tergolong kedalam tumbuhan mangrove muda. Kerapatan mangrove tertinggi adalah jenis Rhizophora apiculata (75\%), dan jenis Avicennia marinna (25\%). Hal yang serupa terlihat pada frekuensi relatif jenis Rhizophora apiculata (66.67\%), dan jenis Avicennia marinna (33.33\%), sedangkan untuk dominasi relatif Rhizophora apiculata (78.70\%), dan jenis Avicennia marinna (21.30\%)
(Gambar 2.). INP jenis tertinggi terlihat pada jenis Rhizophora apiculata (220,36\%) sedangkan jenis Avicennia marinna (79.64\%) (Gambar 3). Pesisir Desa Kembar Maminasa terdapat 7 spesies mangrove (Rahman 2014) dan di Sungai Tallo sebanyak 3 jenis yakni Nypah fruticans, Rhizophora mucronata, dan Avicenia alba (Rahman, 2017). Hasil penelitian ini berbeda dengan penelitian lain yang dilakukan di kampung Teluk Sulaiman oleh Sudiono et al. (2013) mendapatkan 49 jenis mangrove yang terdiri dari 31 jenis mangrove sejati dan 18 jenis mangrove asosiasi.
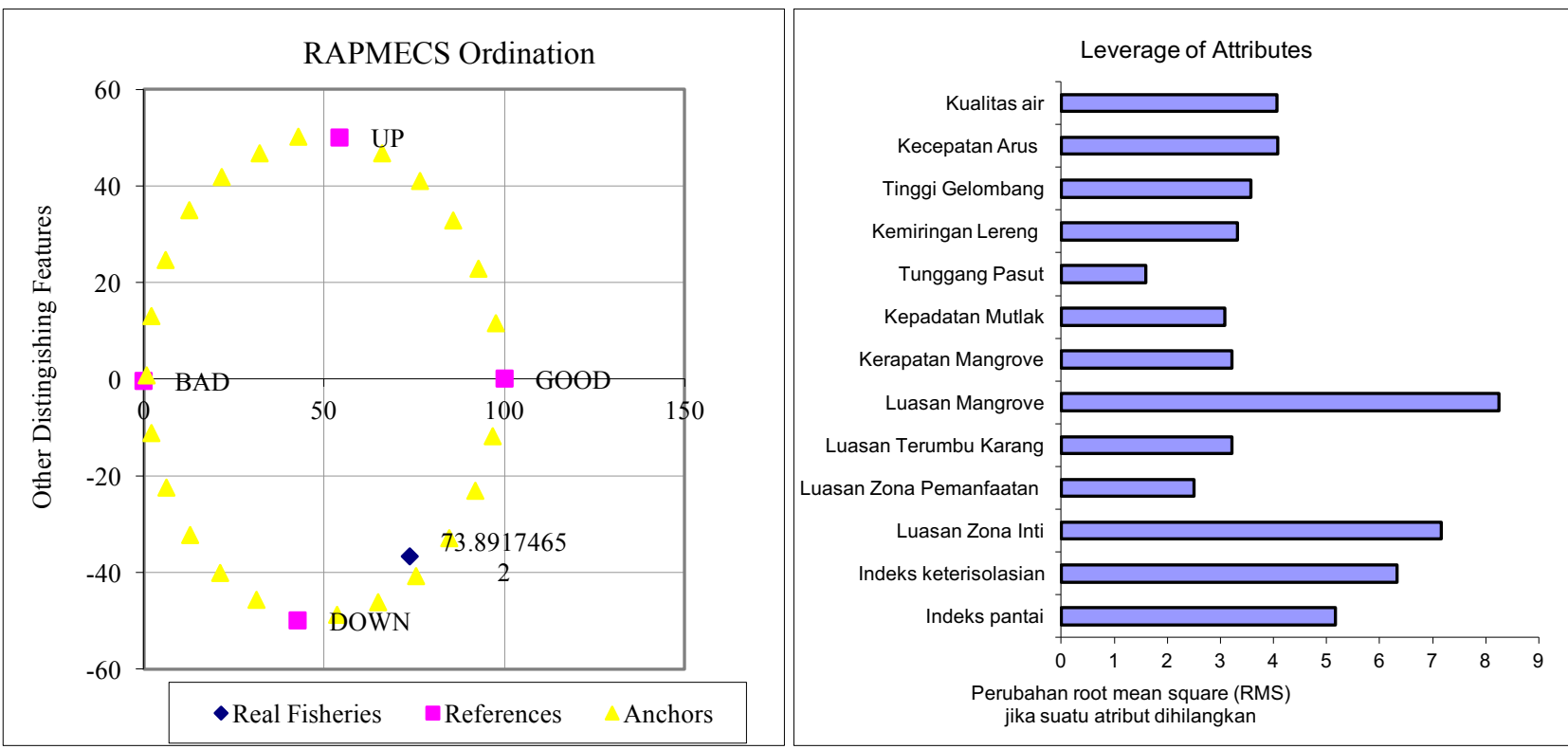

Gambar 4. Indeks Keberlanjutan dan Peran Atribut Dimensi Ekologi

Pada daerah perlindungan lau (DPL) Blongko terdapat empat famili mangrove, dengan tujuh spesies. Famili mangrove tersebut adalah Avicenniaceae, Meliaceae, Rhizophoraceae, dan Sonneratiaceae. Sedangkan spesies mangrove yang ada di desa ini adalah Xylocarpus granatum, Avicennia lanata, Avicennia marina, Avicennia officinalis, Bruguiera gymnorrhiza, Rhizophora apiculata, dan Sonneratia alba (Schaduw, 2015a). Sedangkan Pulau Mantehage yang terdapat pada kawasan TNB memiliki 8 jenis mangrove yang terdiri dari tiga famili. Jenis-jenis yang ada yaitu : Rhizophora apiculata, Rhizophora stylosa, Rhizophora mucronata, Bruguiera gymnorrhiza, Bruguiera cylindrical, Sonneratia alba, Ceriops tagal, Lumnitzera littorea, jenis-jenis mangrove tersebut termasuk dalam famili Rhizophoraceae, Sonneratiaceae, dan Combretaceae (Lahabu, et al. 2015). Pulau Bunaken yang posisinya berdekatan dengan Pulau Nain memiliki lima jenis mangrove yaitu Soneratia alba, Avicennia marina, Xylocarpus granatum, Rhizophora apiculata, dan Bruguiera gymnorrhiza, yang terbagi dalam empat family yaitu Sonneratiaceae, Avicenniaceae, Meliaceae, dan Rhizophoraceae (Schaduw, 2016). Hasil penelitian yang dilakukan pada ekosistem mangrove yang ada di Taman Nasional Sembilang terdapat 8 jenis tumbuhan mangrove antara lain: Excoecaria agallocha, Rhizophora apiculata, Avicennia alba, Rhizophora mucronata, Avicennia officinalis, Brugueira gymnorrhiza, Xylocarpus granatum dan Nypa fruticans (Theresia et al, 2015), sedangkan pada lahan mangrove di Sidoarjo yang memiliki tipe dataran pantai didominasi jenis Rhizopora $s p$, Avicennia $S p$ dan Excoecaria Sp (Kusumastuti et al, 2011).

Manfaat tidak langsung dari ekosistem mangrove dirasakan lebih tinggi jika dibandingkan manfaat langsungnya. Nilai penting ekosistem mangrove antara lain menurunkan tingkat erosi di pantai dan sungai, mencegah banjir, mencegah intrusi air laut, menurunkan tingkat polusi (pencemaran) produksi bahan organik sebagai sumber makanan, sebagai wilayah/daerah asuhan, pemijahan, dan mencari makan untuk berbagai jenis biota laut. Mangrove juga akan menjadi sumberdaya penting dalam ekowisata di banyak negara. Pada kenyataannya ekosistem ini menjaga kestabilan garis pantai, menyediakan penghalang alami dari badai, 
taufan, pasang surut yang tidak menentu dan bencana alam lainnya. Untuk beberapa kasus, ekosistem mangrove juga telah berkontribusi secara signifikan terhadap kehidupan sosial ekonomi masyarakat disekitarnya. Kontribusi yang paling penting dari hutan mangrove dalam kaitannya dengan ekosistem pantai adalah serasah daunnya. Diperkirakan hutan mangrove mampu menghasilkan bahan organik dari serasah daun sebanyak 7-8 ton/ha/tahun. Tingginya produktivitas ini disebabkan karena hanya $7 \%$ dari dedaunan yang dihasilkan dikonsumsi langsung oleh hewan di dalamnya, sedangkan sisanya oleh makroorganisme (terutama kepiting) dan organisme pengurai diubah sebagai detritus atau bahan organik mati dan memasuki sistem energi.

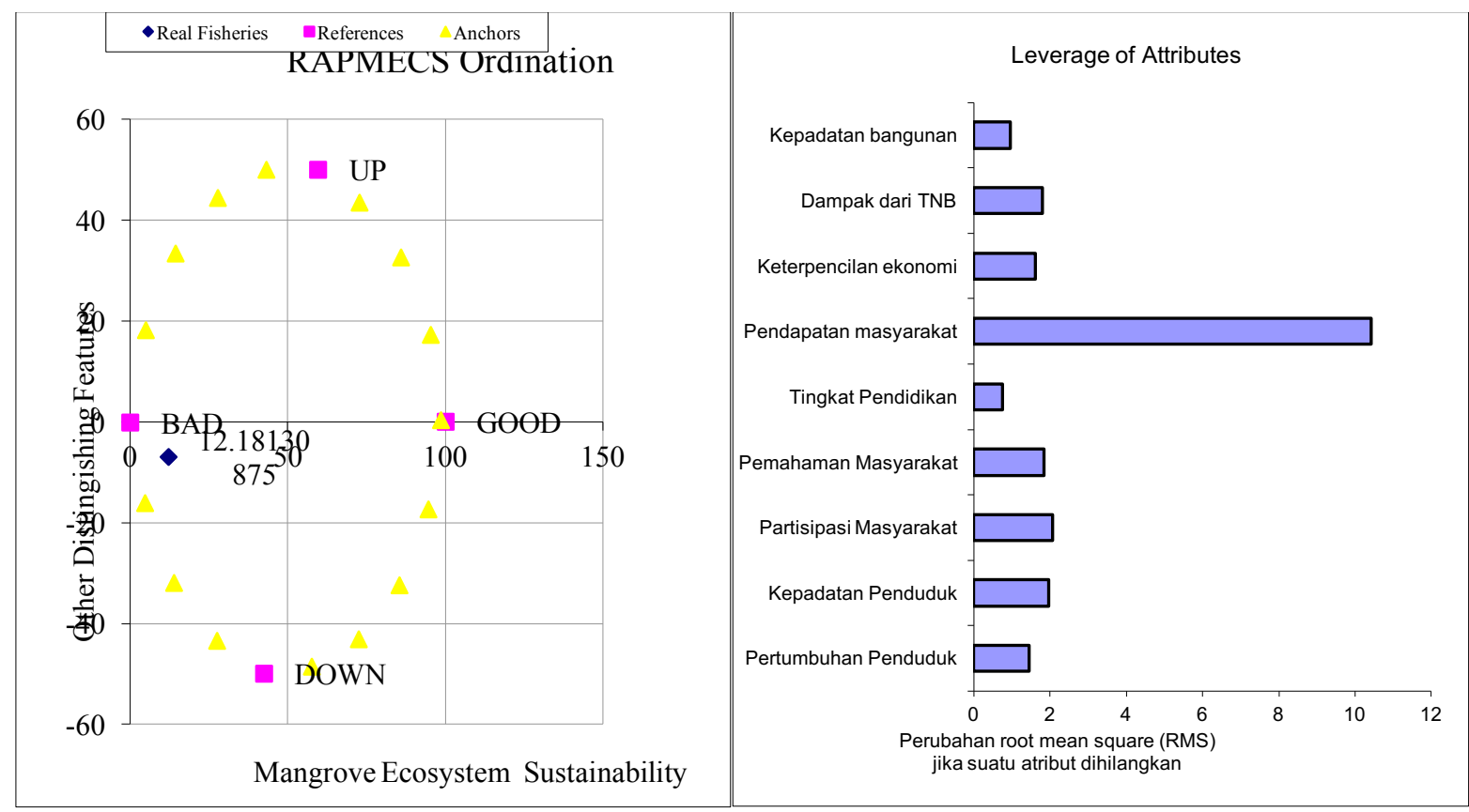

Gambar 5. Indeks Keberlanjutan dan Peran Atribut Dimensi Sosial Ekonomi

\subsection{Keberlanjutan Dimensi Ekologi}

Indeks keberlanjutan pengelolaan ekosistem mangrove pulau Nain menunjukkan angka 73.89, berdasarkan angka ini dapat dikatakan pengelolan dimensi ini dalam keadaan baik. Dimensi ini mendapat pengaruh negatif dari atribut luasan mangrove dan luas zona inti yang kecil, keterisolasian pulau dari daratan yang besar, dan indeks pantai yang kurang baik. Sedangkan atribut yang bersifat posistif ialah kondisi terumbu karang dan kualitas air yang baik serta kerapatan mangrove yang masih baik. Mengingat titik ini berada diantara titik baik tetapi berada dibawah maka diperlukan usaha yang besar untuk mempertahankan kondisi ini. Gambar 4. akan menampilkan keberlanjutan dari pengelolaan serta atribut yang mempunyai peran penting yang mempengaruhi pengelolaan ini. Penanaman mangrove dan optimasi kawasan zona pesisir akan mampu mengangkat dimensi ini kearah yang lebih baik. Sedangkan untuk kualitas air tetap dijaga agar menunjang pelestarian ekosistem pesisir yang ada. Berbeda halnya dengan Pulau Mantehage, keberlanjutan pengelolaan ekosistem mangrove pada Pulau Mantehage memiliki nilai 45.87 (Cukup baik), empat atribut terpentingnya adalah luasan mangrove yang luas, tunggang pasut rendah, kemiringan lereng yang landai dan luasan terumbu karang yang besar
(Schaduw, 2015b). Kajian Pattimahu et al. (2010) di Kabupaten Seram bagian barat memiliki indeks keberlanjutan dimensi ekologi sebesar 79,95 (Baik). Indikator yang diperkirakan memberikan pengaruh terhadap dimensi ekologi terdiri dari enam indikator, yaitu rantai makanan dan ekosistem; perubahan kualitas air; ukuran populasi dan struktur demografi; tingkat kekayaan/keragaman hutan mangrove; struktur relung komunitas, dan perubahan keragaman habitat. Analisis keberlanjutan pengelolaan hutan lindung mangrove di Batu Ampar, Kabupaten Kubu Raya, Provinsi Kalimantan Barat menunjukan nilai indeks keberlanjutan ekologi sebesar 54,59\%, dengan Indikator kunci yang diperkirakan paling berpengaruh terhadap keberlanjutan kriteria ekologi sebanyak 4 indikator, yaitu: (1) penataan batas kawasan (2) kesesuaian peruntukan kawasan (3) ketersediaan bibit tanaman mangrove dan (4) perlindungan terhadap flora dan fauna (Karlina et al 2016). Keberlanjutan pengelolaan mangrove dimensi ekologi di Sidodadi hanya memiliki nilai indeks 41,55\% (cukup baik), terdapat tiga indikator termasuk kategori sensitif dalam mempengaruhi status keberlanjutan pada dimensi ekologi yaitu: (1) keberhasilan rehabilitasi, (2) proporsi luas hutan mangrove dibandingkan kawasan budidaya, serta (3) komposisi jenis mangrove (Muchlis et al. 2014). Indeks keberlajutan pengelolaan 
di Taman Nasional Sembilang sebesar 66,45 ( cukup baik), karena nilai indeks yang dihasilkan berada pada selang nilai 51-75 (Suliso 2003), atribut yang sangat sensitif terhadap nilai indeks keberlanjutan ekologi, yaitu perubahan luasan mangrove (Theresia et al. 2015).

Dampak yang ditimbulkan dengan adanya rehabilitasi hutan mangrove antara lain meningkatnya produksi garam/ikan, mengurangi abrasi pantai, menahan tiupan angin dari laut ke darat, semakin banyak tangkapan biota (udang, kepiting, kerang) di pesisir, dan menjadikan kawasan tersebut menjadi daerah objek wisata (Utomo et al, 2017). Sistem di alam dapat berjalan secara alamiah membentuk kesetimbangan, sehingga tidak dikenal konsep kerusakan lingkungan karena faktor alam. Kerusakan lingkungan terjadi karena ulah campur tangan manusia yang mengakibatkan kesetimbangan alam terganggu. Disamping itu, konsep kerusakan lingkungan yang lebih dikenal apabila gangguan yang terjadi pada alam berimplikasi terhadap kehidupan manusia. Apabila gangguan manusia melebihi daya dukung lingkungan alam maka alam tidak mampu untuk merehabilitasi secara alami, sehingga dibutuhkan campur tangan manusia untuk memperbaiki alam tersebut (Akbar et al, 2017).

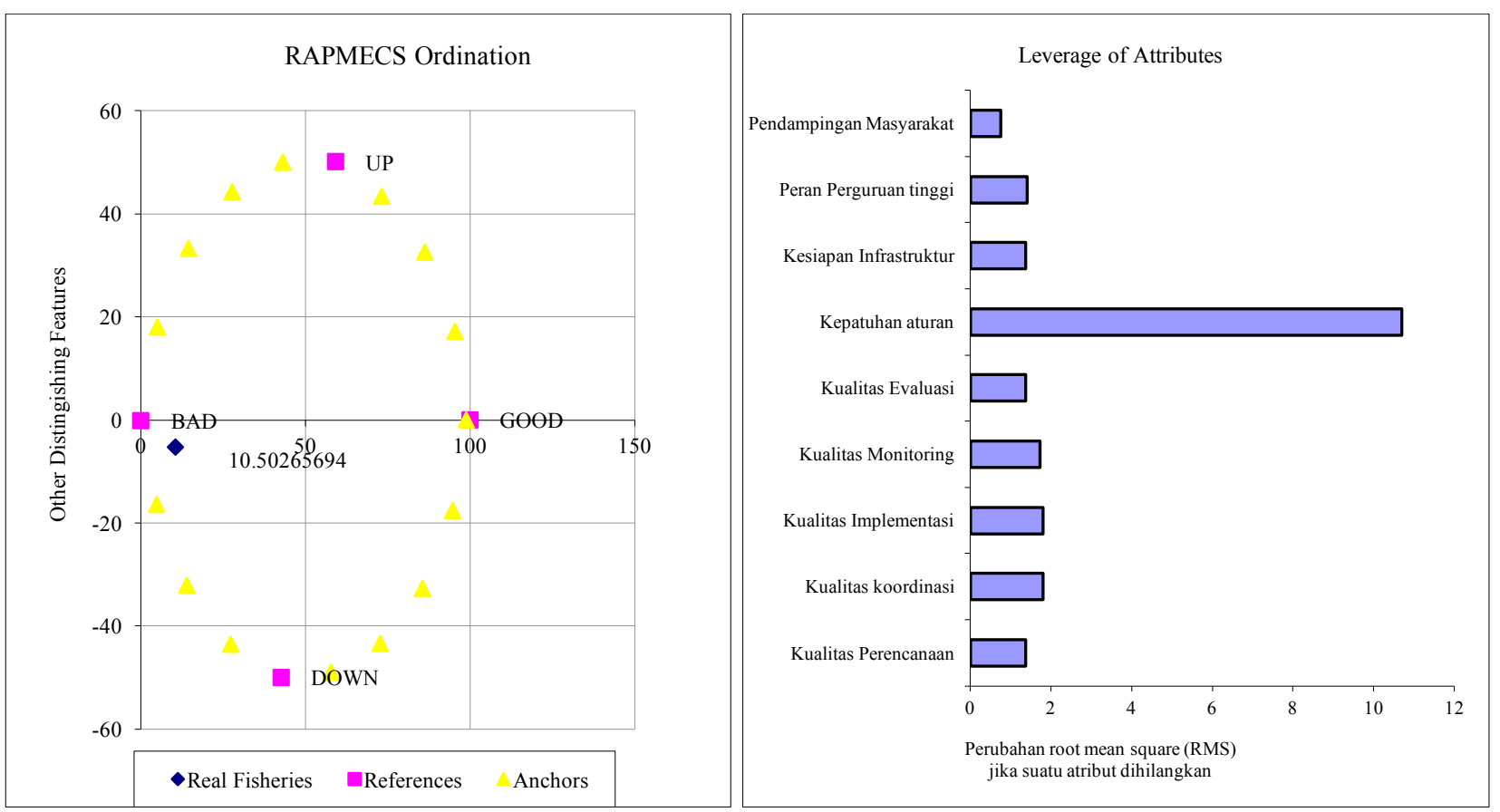

Gambar 6. Indeks Keberlanjutan dan Peran Atribut Dimensi Kelembagaan

\subsection{Keberlanjutan Dimensi Sosial Ekonomi}

Indeks keberlanjutan pengelolaan ekosistem mangrove Pulau Nain pada dimensi sosial ekonomi berada pada nilai 12,18 . Hal ini menunjukkan dalam keberlanjutan pengelolaannya dimensi ini sangat buruk. Beberapa faktor yang mempengaruhi indeks ini ke arah negatif adalah kepadatan penduduk yang tinggi, tingkat partisipasi yang rendah dan pemahaman masyarakat yang masih rendah tentang fungsi ekosistem mangrove. Sedangkan untuk atribut yang memberikan konteribusi positif yaitu pendapatan masyarakat yang baik dibandingkan pulau yang lain. Masyarakat pulau ini menggantungkan ekonominya terhadap hasil rumput laut, akan tetapi perlu diingat bahwa untuk meningkatkan produksi dari rumput laut masyarakat pulau ini menggunakan kayu mangrove untuk membuat meja sebagai tempat untuk menjemur rumput laut tersebut. Hal ini harus diminimalkan untuk mencegah keruskan ekosistem mangrove pulau ini khususnya dan kawasan TNB umumnya.
Gambar 5 akan menampilkan posisi indeks keberlanjutan dan atribut penting yang mempengaruhinya. Lain halnya dengan keberlanjutan pengelolaan ekosistem mangrove Pulau Mantehage, untuk dimensi sosek menunjukkan angka 68.02 dengan faktor pengungkit antara lain tingkat pendidikan dan pendapatan masyarakat di pulau ini yang masih sangat rendah (Schaduw, 2015). Keberlanjutan pengelolaan mangrove di Taman Nasional Sembilang dimensi sosial memiliki nilai indeks sebesar 21,53 (buruk), dengan atribut yang sangat sensitif yaitu kurangnya peningkatan pengetahuan masyarakat tentang mangrove (Theresia et al. 2015). Bebeda halnya dengan indeks dimensi sosial dan ekonomi masing-masing 57,01 dan 36,57 di Desa Sidodadi, dengan faktor pengungkit yaitu popuasi yang memanfaatkan sumberdaya mangrove tinggi dan tingkat pendidikan masyarakat yang masih rendah (Mukhlisi et al, 2014). Pada ekosistem mangrove Batu Ampar, indeks keberlanjutuan pengelolaan mangrove dimensi sosial 
$42,03 \%$ (cukup baik), dengan indikator kunci pada kriteria ini sebanyak empat yaitu: (1) mekanisme resolusi konflik lahan yang efektif sebesar (2) praktek budaya lokal dalam pelestarian hutan lindung mangrove (3) ketersediaan organisasi masyarakat dalam pengelolaan hutan lindung mangrove dan (4) keterlibatan masyarakat dalam pengelolaan kawasan hutan lindung mangrove, sedangkan nilai indeks keberlanjutan pada dimensi ekonomi adalah 34,06 (buruk), status keberlanjutan ini ditentukan oleh dua indikator kunci yang paling berpengaruh, yaitu pendapatan pemerintah dari pengelolaan dan Pemanfaatan hutan lindung mangrove serta tingkat pendapatan masyarakat sekitar hutan (Karlina et al. 2016). Pada ekosistem mangrove di Seram, indeks keberlanjutan dimensi ekonomi sebesar 33,56, dengan tiga indikator yang sensitif terhadap nilai indeks keberlanjutan dimensi ekonomi, yaitu (1) tersedianya hasil pemanfaatan hutan mangrove; (2) tersedia zonasi untuk berbagai tujuan pengelolaan, dan (3) pengelolaan hutan mangrove yang melibatkan berbagai stakeholder, sedangkan untuk dimensi sosial sebesar 22,96, dengan tiga indikator yang sensitif terhadap nilai indeks keberlanjutan dimensi sosial, yaitu (1) perusakan sumber daya hutan oleh masyarakat, (2) akses masyarakat lokal, dan (3) tingkat pendidikan masyarakat (Pattimahu et al, 2010). Kajian pada kawasan hutan mangrove Tugurejo (KMHT) menyimpulkan dengan tingkat pendidikan yang cukup baik dan terbentuknya persepsi masyarakat yang positif terhadap KMTH telah memberikan pengaruh terhadap partisipasi masyarakat terhadap pengelolaan lingkungan KHMT, yang ditunjukkan dengan tingginya keinginan masyarakat untuk menjaga, melestarikan, dan mengharapkan adanya upaya perlindungan dan perbaikan KHMT. Bentuk partisipasi masyarakat adalah sukarela, yaitu dengan kegiatan rutin mereka, seperti melakukan perbaikan tambak. Dengan adanya kepedulian lingkungan masyarakat setempat terhadap KHMT, maka dapat dikatakan bahwa bentuk partisipasi masyarakat adalah manajemen sendiri (self management), karena terbentuk dengan sendirinya atas kesadaran lingkungan masyarakat setempat (Diarto et al, 2012).

\subsection{Keberlanjutan Dimensi Kelembagaan}

Indeks keberlanjutan pengelolaan ekosistem mangrove ditinjau dari dimensi kelembagaan berada pada posisi sangat buruk. Indeks ini hanya mencapai 10,50 , rendahnya indeks ini dipengaruhi oleh atribut rendahnya kualitas koordinasi, implementasi dan monitoring yang sangat buruk, sedangkan satusatunya indeks yang baik adalah indeks kepatuhan terhadap aturan. Jaraknya yang jauh dari daratan dan minimnya sarana transportasi membuat pulau ini seperti kurang diperhatikan oleh pihak pengelola. Hal yang cukup membanggakan bahwa kesadaran masyrakat pulau ini masih baik dalam melestarikan mangrove yang mereka miliki. Membutuhkan energi yang besar untuk mengangkat indeks ini kekeadaan yang lebih baik. Sekarang yang diperlukan adalah keterlibatan semua pihak dalam memperbaiki sistem pengelolaan yang belum optimal pada pulau ini. Gambar 6 akan menampilkan posisi keberlanjutan pengelolaan ekosistem mangrove dan atribut penting yang mempengaruhi dimensi ini. Keberlanjutan pengelolaan ekosistem mangrove Pulau Mantehage pada dimensi kelembagaan menujukkan nilai yang baik yaitu 73.43 dengan faktor pengungkit yaitu ketaatan terhadap aturan yang direpresentasikan melalui jumlah pelanggaran, peran perguruan tinggi dan kualitas dari monitoring (Schaduw, 2015b). Kajian yang dilakukan pada ekosistem mangrove Desa Sidodadi memiliki nilai indeks kelembagaan 69,96 dengan 4 indikator yang sensitif meliputi (1) konsistensi penegakan hukum, (2) peraturan pengelolaan hutan mangrove (3) koordinasi antar lembaga, serta (4) frekuensi konflik (Mukhlisi, 2014). Sedangkan pada Taman Nasional Sembilang indeks keberlanjutan dimensi kelembagaan sebesar 52,36, dengan faktor pengungkit tingkat sinergisitas kebijakan dan pengelolaan mangrove serta kepatuhan terhadap aturan-aturan pengelolaan (Theresia et al. 2015).

\subsection{Keberlanjutan Pengelolaan Ekosistem Mangrove Pulau Nain}

Status keberlanjutan pengelolaan ekosistem mangrove Pulau Nain menunjukkan angka 46.89 yang berarti status keberlanjutan pengelolaan ekosistem mangrove pulau ini berada dalam kondisi cukup baik (Gambar. 7). Keterisolasian pulau, luasan mangrove yang kecil, luas pulau yang kecil dan rendahnya kualitas sumberdaya manusia membuat pulau ini memiliki nilai yang buruk untuk nilai keberlanjutan pengelolaan ekosistem mangrove Pulau Nain. Status dari keberlanjutan pengelolaan Pulau Nain dapat ditingkatkan melalui peningkatan peran serta pengelola yang dalam hal ini adalah pemerintah untuk meningkatkan kualitas pengelolaan khususnya dimensi sosial ekonomi dan kelembagaan. Berbeda halnya dengan status keberlanjutan pengelolaan ekosistem mangrove Pulau Mantehage yang termasuk kategori baik $(59,34)$, akan tetapi satu dari tiga dimensi di Pulau Mantehage memiliki nilai yang rendah yaitu dimensi ekologi (Schaduw, 2015b). Keberlanjutan pengelolaan ekosistem hutan mangrove di Kabupaten Seram Bagian Barat Maluku menunjukkan nilai indeks keberlanjutan sebesar 36,08 dan termasuk dalam status keberlanjutan yang buruk, dengan indikator yang sensitif sebanyak enam indikator, yaitu (1) data pemanfaatan hutan mangrove; (2) zonasi mangrove; (3) keterlibatan stakeholder; (4) perusakan sumber daya hutan; (5) akses masyarakat lokal dan (6) tingkat pendidikan masyarakat (Pattumahu et al, 2010). Status keberlanjutan pengelolaan hutan lindung mangrove di Kecamatan Batu Ampar adalah baik (54,59\%) pada kriteria ekologi; buruk pada kriteria ekonomi 
$(34,06 \%)$ dan kriteria cukup baik pada kriteria sosial $(42,03 \%)$. Masing-masing kriteria memiliki indikator kunci sebagai faktor yang berpengaruh terhadap status keberlanjutan pengelolaan tersebut. Indikator yang berpengaruh terhadap status keberlanjutan pengelolaan hutan lindung mangrove pada kriteria ekologi yaitu: penataan batas kawasan, kesesuaian peruntukan kawasan sebesar, ketersediaan bibit tanaman mangrove, dan perlindungan terhadap flora dan fauna. Indikator berpengaruh pada kriteria ekonomi yaitu: pendapatan pemerintah dari pengelolaan dan pemanfaatan hutan lindung mangrove, dan tingkat pendapatan masyarakat sekitar hutan. Indikator berpengaruh pada kriteria sosial yaitu: mekanisme resolusi konflik lahan yang efektif, praktek budaya lokal dalam pelestarian hutan lindung mangrove, ketersediaan organisasi masyarakat dalam pengelolaan hutan lindung mangrove, dan keterlibatan masyarakat dalam pengelolaan kawasan hutan lindung mangrove (Karlina et al. 2016).

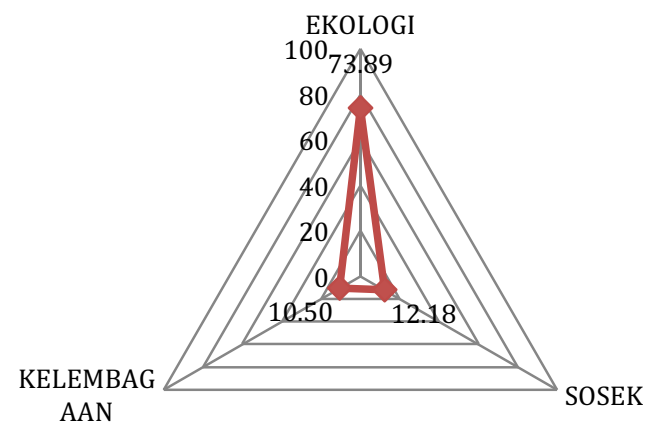

Gambar 7. Indeks Keberlanjutan Pengelolaan Ekosistem Mangrove Pulau Nain

Desa Sidodadi memiliki indeks berkelanjutan pengelolaan mangrove dengan nilai 55,63, jika ditinjau keberlanjutan dari masing-masing dimensi maka dapat dinyatakan bahwa dimensi ekologi dan ekonomi masuk ke dalam status kurang berkelanjutan. Sementara itu, dimensi sosial beserta dimensi hukum dan kelembagaan keduanya memiliki status cukup berkelanjutan (Mukhlisi et al, 2014). Status keberlanjutan pengelolaan ekosistem mangrove di Taman Nasional Sembilang Kabupaten Banyuasin Provinsi Sumatera Selatan berada dalam kategori cukup baik $(49,81)$, dengan rekomendasi strategi pengelolaan yaitu pemberdayaan masyarakat, pendidikan dan pelatihan sumber daya manusia serta rehabilitasi, konservasi dan pemeliharaan ekosistem mangrove, yang menjadi salah satu strategi untuk meningkatkan status keberlanjutan pengelolaan ekosistem mangrove di Taman Nasional Sembilang Kab. Banyuasin Sumatera Selatan agar dapat berkelanjutan (Theresia et al, 2015). Melihat hasil kajian di Pulau Nain, ekosistem 128 mangrove yang ada di Pulau ini dapat dikembangkan menjadi kawasan ekoswisata. Ekowisata bahari (Ecotourism, green tourism atau alternative tourism), merupakan wisata yang berorientasi pada lingkungan bahari yang memanfaatkan karakter sumberdaya pesisir dan laut, dalam memberikan sumbangan positif kepada upaya pelestarian berwawasan lingkungan melalui tindakan konservasi atau menyelamatkan lingkungan. Berdasarkan pengertian ekowisata diatas maka dapat dirumuskan faktorfaktor dari prinsip utama dasar pelaksanaan kegiatan ecotourism yaitu faktor Jasa lingkungan non market dari manfaat kegiatan sosial, ekonomi dan ekologi (Pieter et al, 2015)

\section{Kesimpulan dan Saran}

Pulau Nain memiliki dua jenis mangrove yaitu jenis Rhizophora apiculata dan Avicennia marinna masingmasing dari family Avicenniaceae dan Rhizophoraceae, dengan luasan mangrove 4,40 ha, jarak antar pohon 1,02 m, dan kepadatan pohon 95,65 ind/ha termasuk kategori ekosistem mangrove yang sangat padat. Tidak ada indikasi degradasi ekosistem mangrove pada pulau ini. Keberlanjutan pengelolaan ekosistem mangrove Pulau Nain secara keseluruhan berada pada posisi yang cukup baik, akan tetapi posisi ini sangat rentan karena memiliki kekurangan pada dimensi sosial ekonomi dan kelembagaan. Faktor pengungkit utama dimensi ekologi adalah luasan mangrove yang perlu diperluas, dimensi sosek adalah peningkatan pendapatan masyarakat, dan dimensi kelembagaan adalah peningkatan kepatuhan terhadap aturan.

\section{Ucapan Terima Kasih}

Penulis mengucapkan terima kasih kepada Pusat Penelitian Oseanografi Lembaga Pengetahuan Indonesia, melalui pelaksanaan kegiatan penelitian Program Demand Driven Research COREMAP-CTI, karena sebagian dari kegiatan penelitian dan kelanjutan dibiayai oleh P20 LIPI. Ucapan yang sama di tujukan kepada Dinas Pariwisata Sulut, Dinas Kelautan dan Perikanan Provinsi Sulawesi Utara; Balai Taman Nasional Bunaken (BTNB); World Wildlife Fund (WWF); Pemerintah Kecamatan Wori dan Kabupaten Minahasa Utara; Fakultas Perikanan dan Ilmu Kelautan Universitas Sam Ratulangi, serta semua pihak yang terlibat dalam penelitian ini.

\section{Daftar Pustaka}

Akbar A.A, J Sartohadi, T Sugandawaty, Djohan, S Ritohardoyo. 2017. Erosi Pantai, Ekosistem Hutan Bakau Dan Adaptasi Masyarakat Terhadap Bencana Kerusakan Pantai Di Negara Tropis. Jurnal Ilmu Lingkungan 15 (1):1-10

Alder J, T.J. Pitcher, D. Preikshot, K. Kaschner, and B. Feriss. 2000. How good is good? A rapid appraisal technique for evaluation of the sustainable statusof fisheriesof the North Atlantic. In Pauly and Pitcher (eds.). Methods forevaluation the impact of fisheries on the 
North Atlantic ecosystem. Fisheries Center Research Reports. 8(2):15-22.

Bakus GJ. 2007. Quantitatif Analysis of Marine Biological Communities Field Biology and Environmental. New Jersey: John Wiley \& Sons Inc.

Cisse A.A, B. Fabian, and G. Oliver. 2014. Sustainability of tropical small-scale fisheries: integrated assessmentin french guana. Marine Policy. 44:397- 405.

Diarto, B Hendrarto, S Suryoko. 2012. Partisipasi Mayarakat Dalam Pengelolaan Lingkungan Kawasan Hutan Mangrove Tugurejo Di Kota Semarang. Jurnal Ilmu Lingkungan. 10 (1) : 1-7

Fauzi A. dan S. Anna. 2005. Pemodelan sumberdaya perikanan dan kelautan untuk analisis kebijakan. PT. Gramedia Pustaka Utama. Jakarta.

Hair JF, Anderson RE, Tatham RL, Black WC. 1998. Multivariate Data Analysis. New York: Prentice Hall International Inc.

Karlina E, C Kusmana, Marimin, dan M. Bismark. 2016. Analisis Keberlanjutan Pengelolaan Hutan Lindung Mangrove Di Batu Ampar, Kabupaten Kubu Raya, Provinsi Kalimantan Barat. Jurnal Analisis Kebijakan. 13 (3): 201-219

Kavanagh P. 2001. Rapid Appraisalof Fishereis (RAPFISH) Project. RAPFISH software descreption (for Microsoft Excel). University of British Columbia, Fisheries Centre, Vancouver. Fisheries Centre Research. 2 (12). DOI. 10.14288/1.007.4801

Kusmana C, Sri W, Iwan H, Prijanto P, Cahyo W, Tatang T, Adi T, Yunasfi, Hamzah. 2005. Teknik Rehabilitasi Mangrove. Bogor: Fakultas Kehutanan. Institut Pertanian Bogor.

Kusumastanto T. 2002. Reposisi Ocean Policy Dalam Pembangunan Ekonomi Indonesia di Era Otonomi Daerah. Disampaikan. Bogor: Di dalam Orasi Ilmiah Pengukuhan Guru Besar Tetap Bidang Ilmu Kebijakan Ekonomi Perikanan dan Kelautan FPIK IPB.

Kusumastuti W, B Hendrarto, D Sutrisnanto. Evaluasi Lahan Basah Buatan Vegetasi Mangrove Dalam Mengurangi Pencemaran Lingkungan (Studi Kasus di Desa Kepetingan Kabupaten Sidoarjo). Jurnal Ilmu Lingkungan. 9 (2): 69-74

Lahabu Y, J.N.W. Schaduw, dan A.B. Windarto. 2015. Kondisi Ekologi Mangrove Di Pulau Mantehage Kecamatan Wori Kabupaten Minahasa Utara Provinsi Sulawesi Utara, Jurnal Pesisir dan Laut Tropis. 2 (1) : 41-52

Mukhlisi, IB. Hendrarto dan H Purnaweni. 2014. Status keberlanjutan pengelolaan hutan mangrove di desa Sidodadi kecamatan padang cermin kabupaten pesawaran Provinsi lampung. Jurnal Geografi. 11 (1) : 58-70

Pattimahu DV, C Kusmana, H Harjomidjojo dan D Darusman. 2010. Analisis Nilai Keberlanjutan Pengelolaan Ekosistem Hutan Mangrove Di Kabupaten Seram Bagian Barat, Maluku. Forum Pascasarjana. 33 (4):239-249

Pieter J, F Benu, M.R. Kaho. 2015. Valuasi Ekonomi Ekowisata Terhadap Pengembangan Objek Wisata Kawasan Pesisir Pantai (Studi Kasus Jasa Lingkungan Non-Market Sumberdaya Alam Objek Wisata Pesisir Pantai Lasiana Kecamatan Kelapa Lima Kota Kupang Provinsi NTT). Jurnal Ilmu Lingkungan. 13(1): 55-64

Pitcher, T.J. 1999. RAPFISH a rapid appraisal technique for fisheries and Its application to the code conduct for responsible fisheries FAO Fisheries Circular No. 947. Rome.
Pitcher T.J and D. Preikshot. 2001. RAPFISH: a rapid appraisal technique to evaluate the sustainability status of fisheries. Fisheries Research, 49 (2001) : 255270.

Schaduw J.N.W. 2015a. Bioekologi Mangrove Daerah Perlindungan Laut Berbasis Masyarakat Desa Blongko Kecamatan Sinonsayang Kabupaten Minsel Provinsi Sulut. Jurnal LPPM UNSRAT bidang Sains dan Teknologi. 2 (1) : 90-102

Schaduw J.N.W. 2015b. Keberlanjutan Pengelolaan Ekosistem Mangrove Pulau Mantehage, Kecamatan Wori, Kabupaten Minahasa Utara, Provinsi Sulawesi Utara, Jurnal LPPM UNSRAT bidang Sains dan Teknologi. 2 (2) : 60-70

Schaduw J.N.W. 2016. Kondisi Ekologi Mangrove Pulau Bunaken Kota Manado Provinsi Sulawesi Utara. Jurnal Sains LPPM UNSRAT bidang Sains dan Teknologi. 3 (2) : 64-74

Sudiono E, Sasmirul A, Purwnomo, Jasari, Sujoko, U, Sahri A. 2013. Laporan Survey Biodiversitas Kawasan Mangrove Teluk Sulaiman dan Tata Batas kawasan Lindung dan Wisata Alam Labuan Cermin, kecamatan Biduk-Biduk, Kabupaten Berau (Laporan Internal). The Nature Conservancy. Berau.

Susilo S.B. 2003. Keberlanjutan Pembangunan Pulau-Pulau Kecil: Studi Kasus Kelurahan Pulau Panggang dan Pulau Pari Kepulauan Seribu DKI Jakarta. Disertasi (Tidak dipublikasikan). Institut Pertanian Bogor. Bogor.

Theresia, M Boer, Niken dan T.M Pratiwi. 2015. Status Keberlanjutan Pengelolaan Ekosistem Mangrove Di Taman Nasional Sembilang Kabupaten Banyuasin Provinsi Sumatera Selatan. Jurnal Ilmu dan Teknologi Kelautan Tropis.7 (2) : 703-714

Utomo B, S Budiastuti, C Muryani. 2017. Strategi Pengelolaan Hutan Mangrove Di Desa Tanggul Tlare Kecamatan Kedung Kabupaten Jepara. Jurnal Ilmu Lingkungan. 15 (2) : 117-123 